MARIUSz GrabowsKI ${ }^{*}$

\title{
W SPRAWIE POJĘCIA UCZCIWEJ REKLAMY W MEDIACH zawartego w nauczaniu Jana Pawea II
}

\section{Uwagi wstępne}

Nauczanie Jana Pawła II wyrażone w Jego publicznych wypowiedziach oraz w dokumentach Stolicy Apostolskiej wydanych za Jego pontyfikatu, dotyczące dopuszczalnych ram działalności o charakterze promocyjnym, nie jest dostatecznie znane i doceniane, w szczególności w tzw. świecie mediów. Jest to istotny brak, zwłaszcza, gdy dostrzegamy go w ojczyźnie Jana Pawła II. Pomimo tego, że w nauczaniu tym mamy do czynienia zarówno z postulatami pod adresem prawodawców krajowych i międzynarodowych, jak i pod adresem uczestników rynku mediów. I nie chodzi tu wyłącznie "tylko" o ogólny postulat etyczności ${ }^{1} \mathrm{w}$ działalności podmiotów uczestniczących w prowadzeniu promocji ${ }^{2}$, ale o konkretne propozycje rozwiązań. Jedne nadają się wprost do recypowania w polskim prawie, a inne wymagają "tylko" przełożenia na właściwy polskiemu systemowi prawnemu język legislacyjny. Z całą pewnością, mamy zaś do czynienia z gotowymi rozwiązaniami, które mogłyby i powinny znaleźć właściwe sobie miejsce w aktach samoregulacyjnych, tzw. kodeksach dobrych obyczajów, których nie brakuje na rynku reklamy (promo-

*Dr, Uniwersytet Kardynała Stefana Wyszyńskiego; e-mail: m.grabowski@uksw.edu.pl.

${ }^{1}$ Wypływający z prawa naturalnego oraz z etyki katolickiej.

2 Przedmiotem artykułu są aspekty prawne a nie natury filozoficznej. 
cji) $\mathrm{w}$ Polsce ${ }^{3}$. Zwłaszcza ten ostatni aspekt jest istotny, gdyż stosowanie przez uczestników rynku mediów norm dobrych obyczajów, ma z reguły większy wpływ na praktykę życia społecznego i ekonomicznego, niż litera powszechnie obowiązującego prawa - w myśl maksymy: „czymże są prawa bez obyczajów”. Ponadto normy te nabierają dodatkowego znaczenia $\mathrm{w}$ tych sytuacjach, w których przepisy powszechnie obowiązującego prawa bezpośrednio się do tych norm odwołuja, czy też w przypadkach, w których prawo pozytywne „milczy”.

Celem artykułu jest $\mathrm{z}$ jednej strony przybliżenie nauczania Jana Pawła II w przedmiotowym zakresie, a z drugiej strony analiza tego nauczania pod kątem jego recepcji w polskim prawie stanowionym. Ma to służyć nie tylko celom opisowym, ale przede wszystkim formułowaniu postulatów de lege ferenda, tak w niniejszej wypowiedzi, jak i w przyszłych, do których być może ten artykuł się przyczyni. Wszystko to w aspekcie postulatu recepcji nauczania Jana Pawła II.

Poniżej odwołuję się do istotnych i charakterystycznych - na potrzeby tego artykułu - wypowiedzi Jana Pawła II oraz dokumentów Kościoła wydanych za jego pontyfikatu.

Na wstępie należy podkreślić, że tytułowe nauczanie Jana Pawła II (i dokumenty) nie odwołują się zasadniczo do argumentów natury religijnej. Naczelnym argumentem jest w nich bowiem dobro człowieka i dobro wspólne. A dobra te są przecież racją i istotą prawa w ogóle, w szczególności zaś prawa stanowionego ${ }^{4}$. Toteż tytułowe nauczanie ma charakter uniwersalny.

Wyczerpujące powołanie wszystkich obowiązujących w Polsce przepisów dotyczących promocji wykracza poza ramy artykułu. Ograniczam się do wskazania ram prawnych wystarczających na potrzeby wypowiedzi, zasadniczo poprzestając na płaszczyźnie ustawowej.

Mottem oraz punktem odniesienia zawartych tu rozważań niech będą słowa Jana Pawła II: „podstawowym obowiązkiem twórców reklam, podobnie jak wszystkich innych zawodowo pracujących w innych środkach społecznego przekazu, jest być rzecznikami i promotorami autentycznej

${ }^{3}$ Uwaga ta dotyczy zwłaszcza nadawców określających swój profil programowy jako katolicki.

${ }^{4}$ Warto w tym miejscu przypomnieć naczelna, ustrojową zasadę polskiej Konstytucji, która odwołuje się do pojęcia „dobra wspólnego" wszystkich obywateli, art. 1 Konstytucji Rzeczypospolitej Polskiej z dnia 2 kwietnia 1997 r., Dz. U. z 1997 r. Nr 78, poz. 483; z 2001 r. Nr 28, poz. 319; z 2006 r. Nr 200, poz. 1471; z 2009 r. Nr 114, poz. 946. 
wizji ludzkiego rozwoju w jego wymiarach materialnych, kulturowych i duchowych" ${ }^{5}$.

\section{Pojęcie "reklamy" w nauczaniu papieskim}

Wyjaśnienia wymaga termin „reklama”, z którym mamy do czynienia w nauczaniu Jana Pawła II, w tym w dokumentach Kościoła wydanych za Jego pontyfikatu. Stojąc na gruncie prawa stanowionego, należy stwierdzić, że ten „papieski” termin nie oznacza wyłącznie „reklamy”, jako rodzaju wypowiedzi należącej do szerszego pojęcia "promocji”. W tym wypadku reklamę należy pojmować, jako każdą "promocję", niezależnie od sposobu jej prowadzenia ${ }^{6}$. Toteż będzie nią oprócz samej reklamy, także sponsoring, telesprzedaż, lokowanie produktu (tematu) itd. Ponadto „reklamą" jest tutaj każdy rodzaj promocji, niezależnie od jej przedmiotu, a więc promocja o charakterze komercyjnym (gospodarczym), jak i społeczna (polityczna). Uwagi te są konieczne, gdyż inny jest język prawodawcy polskiego, a inny nauczania Kościoła. Powyższe doprecyzowanie jest istotne, gdyż oznacza, że przedmiot papieskich postulatów w sprawie „reklamy” ma, co do zasady, szerszy zakres niż ten, który jest w polu zainteresowania polskiego prawodawcy. Prawodawca ten koncentruje się raczej na środkach promocji gospodarczej a nie społecznej (politycznej) ${ }^{7}$. Już ten fakt jest przyczynkiem do postulowania zmian de lege ferenda w zakresie reglamentacji prawnej różnych środków ${ }^{8}$ tzw. promocji społecznej (politycznej), w sprawie których polski prawodawca relatywnie ma mniej do powiedzenia.

Za powyższym rozumieniem pojęcia „reklamy” przemawia nie tylko kontekst użycia tego pojęcia w różnych publicznych wypowiedziach, ale także określenia o charakterze definicyjnym użyte w dokumencie Etyka w reklamie, wydanym przez Papieską Radę ds. Środków Społecznego

${ }^{5}$ Jan Paweł II, Solicitudo rei socialis, 27-34, Watykan 1988, s. 547-560.

${ }^{6}$ M. Grabowski, Sponsoring telewizyjny. Aspekty prawne i praktyczne, Kraków 2015, s. 237-238.

${ }^{7}$ Tak jest np. po nowelizacji definicji reklamy w polskiej ustawie o radiofonii i telewizji (o której mowa poniżej), zawężonej obecnie do reklamy gospodarczej.

${ }_{8}^{8}$ Zwłaszcza reklamy i sponsoringu. 
Przekazu ${ }^{9}$. Dokument ten powstał z inicjatywy Jana Pawła II i jest zarazem skonkretyzowaniem postulatów dotyczących promocji zawartych $\mathrm{w}$ całym Jego nauczaniu. Ówczesny papież przywiązywał dużą wagę w swoim nauczaniu do kwestii działalności środków społecznego przekazu i ich wpływu, rzeczywistego, bądź potencjalnego na dobro człowieka. A sam dokument w swej treści odwołuje się do wypowiedzi Jana Pawła II.

Zgodnie z definicją zawartą $\mathrm{w}$ rozdziale I pkt 2 Etyki w reklamie, „reklama to po prostu publiczne ogłoszenie, które ma dostarczać informacji i wzbudzać zainteresowanie oraz określoną reakcję"10. A sama „reklama ma dwa zasadnicze cele: informować i przekonywać". Cytowany pkt 2 odwołuje się do wielu rodzajów „reklamy”, co wskazuje, że chodzi tu o różne środki promocji w szerokim - wyżej przyjętym - znaczeniu. Stwierdza on wprost, że wprawdzie „można wyróżnić wiele typów samej reklamy, [...] sądzimy, że uwagi przedstawione poniżej można odnieść do wszystkich form reklamy".

Takie terminologiczne podejście jest charakterystyczne dla doktryny ekonomicznej, której przedstawiciele pod pojęciem reklamy także umieszczają różne środki promocji ${ }^{11}$. Formułowane tu definicje reklamy generalnie nawiązują do klasycznej definicji reklamy Amerykańskiego Stowarzyszenia Marketingu, zgodnie z którą reklamą jest wszelka płatna forma nieosobowego przedstawiania i popierania produktów, usług oraz idei przez określonego nadawcę ${ }^{12}$.

Natomiast na gruncie doktryny prawnej zawarte powyżej uwagi mają już istotne znaczenie. $W$ nauce prawa mamy już bowiem do czynienia z wyraźnym rozróżnieniem terminologicznym różnych form promocji ${ }^{13}$,

9 Papieska Rada ds. Środków Społecznego Przekazu, Etyka w reklamie, „L' Osservatore Romano" [wyd. pol.] 18(1997), nr 11, s. 40-46.

${ }^{10}$ Te dwie najważniejsze funkcje reklamy, informacyjna i promująca, są eksponowane w doktrynie prawnej, zob. m.in. M. Gajlewicz, Reklama i jej uwarunkowania, „Przegląd Ustawodawstwa Gospodarczego" 1993, nr 10, s. 2-6; tamże w sprawie ekonomicznej, społecznej i psychologicznej funkcji reklamy, J. Preussner-Zamorska, Uwagi na temat zakazu reklamowania wolnych zawodów, "Rejent” 1994, nr 3, s. 15-17.

${ }^{11}$ Oprócz samej reklamy, także np. sponsoring, lokowanie produktu itd.

12 Zob. T. Sztucki, Promocja. Sztuka pozyskiwania nabywców, Warszawa 1995, s. 49; J. Łodzianowska-Grabowska, Efektywność reklamy, Warszawa 1996, s. 13; J. Kall, Reklama, Warszawa 1998, s. 17; L. Garbarski, I. Rutkowski, W. Wrzosek, Marketing. Punkt zwrotny nowoczesnej firmy, Warszawa 2001, s. 517.

${ }_{13}$ Zob. m.in. J. Preussner-Zamorska, Aksjologiczne uwarunkowania reklamy, "Zeszyty Naukowe Uniwersytetu Jagiellońskiego. Prace z Wynalazczości i Ochrony Własności Intelektualnej" 1993, nr 62, s. 60; taż, Uwagi na temat zakazu reklamowania wolnych zawodów, 
takich jak np. reklama, sponsoring, telesprzedaż, lokowanie produktu czy tematu. Oczywiście, ma na to wpływ używana przez prawodawcę terminologia dotycząca różnych środków promocji, w szczególności zaś definicje ustawowe. Toteż ze względu na rozróżnienie, z którym mamy do czynienia $\mathrm{w}$ doktrynie i legislacji, konieczne było sprecyzowanie znaczenia pojęcia „papieskiej” reklamy. W dalszej części pracy pojęcie to należy traktować, jako „promocję" wszędzie tam, gdzie przywołane jest nauczanie Jana Pawła II. To samo dotyczy innych wyróżnionych odmian wyrażenia „reklama”, jak np. „reklamodawcy”. Pod pojęciem tych ostatnich należy rozumieć reklamodawców, sponsorów, lokujących produkty itd. W odniesieniu do elektronicznych środków społecznego przekazu, „papieska” reklama jest "przekazem handlowym” w rozumieniu przepisu art. 4 pkt 16 ustawy o radiofonii i telewizji ${ }^{14}$, zwanej dalej URT.

\section{Problematyka wybranych funkcji „reklamy” w świetle papieskiego nauczania}

W części I dokumentu Etyka w reklamie, znajdujemy podkreślenie roli „reklamy”, której znaczenie jest zarazem uzasadnieniem tego dokumentu. Jest także powodem, dla którego prawodawcy przykładają dużą wagę do problematyki promocji. W pkt 1, zostało zawarte znamienne stwierdzenie, że „reklama, posługująca się środkami przekazu jako nośnikami, jawi się we współczesnym świecie jako wszechobecna, przemożna siła, która wpływa na mentalność i zachowania ludzi". Jednocześnie wyeks-

\footnotetext{
„Rejent” 1994, nr 3, s. 16; B. Jaworska-Dębska, Wokót pojęcia reklamy, „Przegląd Ustawodawstwa Gospodarczego" 1993, nr 12, s. 21; E. Nowińska, Zwalczanie nieuczciwej reklamy. Zagadnienia cywilno-prawne, Kraków 1997, s. 24; R. Skubisz [w:] J. Szwaja (red.), Ustawa o zwalczaniu nieuczciwej konkurencji. Komentarz, Warszawa 1994, s. 140; R. Skubisz [w:] J. Szwaja (red.), Ustawa o zwalczaniu nieuczciwej konkurencji. Komentarz, Warszawa 2006, s. 642; I. Wiszniewska, R. Skubisz, Środki zapobiegania nieuczciwej reklamie w projekcie ustawy o zwalczaniu nieuczciwej konkurencji, „Państwo i Prawo” 1995, nr 4 s. 55; R. Skubisz, Zakaz reklamy napojów alkoholowych, „Rejent” 1995, nr 10, s. 13; M. Grabowski, Sponsoring. Kwalifikacja prawna, Lublin 2013, s. 179-185; Z. Okoń [w:] E. Traple, J. Adamczyk, P. Barta, X. Konarski, W. Kulis, P. Litwiński, Z. Okoń, M. Ożóg, P. Podrecki, G. Sibiga, M. Świerczyński, T. Targosz, Prawo reklamy i promocji, Warszawa 2007, s. 637; M. Gajlewicz, Reklama i pojęcia pokrewne, „Przegląd Ustawodawstwa Gospodarczego” 1993, nr 10, s. 6-9.

${ }^{14}$ Ustawa z dnia 29 grudnia 1992 r. o radiofonii i telewizji, Dz. U. z 2017 r. poz. 1414, 2111.
} 
ponowane jest prawo każdego człowieka i wspólnot ludzkich do takiej informacji, która jest oparta na „prawdzie, wolności, sprawiedliwości i solidarności". Wskazane powody sprawiaja, że Kościół nie może nie zabierać głosu w sprawie „reklamy” ${ }^{15}$. Ważne stwierdzenie, zawiera pkt 3, Etyki w reklamie: „reklama” kształtuje rzeczywistość, toteż fałszywy jest pogląd, zgodnie z którym „reklama” jest jedynie odzwierciedleniem postaw i wartości kulturowych danej społeczności. To właśnie „twórcy reklam wybierają spośród wartości i postaw te, które warto popierać i upowszechniać, krzewiąc jedne, a ignorując inne". Stanowisko to warto wyeksponować, jako istotny argument $\mathrm{w}$ doktrynalnych dyskusjach oraz $\mathrm{w}$ polityce prawodawczej. Zwłaszcza, że wydaje się być ono lekceważone w świetle dominujących obecnie tendencji o charakterze technokratycznym w procesie stanowienia i stosowania prawa.

Drugim ważnym zagadnieniem podniesionym we wstępie cytowanego dokumentu jest „reklama” adresowana do dzieci. Powodem tej egzemplifikacji są szczególne możliwości nadużyć w tej mierze. Ochronie dzieci i młodzieży przed szkodliwymi dla nich treściami poświęcone są - w odniesieniu do mediów elektronicznych - przepisy art. 18 ust. 4-5b URT. Zgodnie z art. 18 ust. 4 URT, zakazane jest rozpowszechnianie "reklam”, które zagrażają fizycznemu, psychicznemu lub moralnemu rozwojowi małoletnich, w szczególności zaś takich, które zawierają treści pornograficzne lub w sposób nieuzasadniony eksponują przemoc ${ }^{16}$. Należy zaznaczyć, że jest to zakaz bezwzględny, obowiązujący przez całą dobę nadawania programu. Niestety zakaz ten jest powszechnie naruszany w praktyce nadawczej w Polsce - także w odniesieniu do audycji - w oparciu o mylną jego interpretację $\mathrm{w}$ zestawieniu $\mathrm{z}$ nakazem $\mathrm{z}$ art. 18 ust. 5 URT. Istotną część odpowiedzialności za taki stan rzeczy wydaje się ponosić Krajowa Rada Radiofonii i Telewizji. Art. 18 ust. 5 URT, zezwala na zamieszczanie „reklam”, ale tych, które „moga” mieć negatywny wpływ na taki rozwój,

15 Zob. Paweł VI, Środki społecznego przekazu: korzyści - niebezpieczeństwa-odpowiedzialność. Orędzie na XI Światowy Dzień Środków Społecznego Przekazu 1977, „L'Osservatore Romano" 13.05.1977, nr 1/2, https://www.paulus.org.pl/256,11-sdssp-pawel-vi-1977 [dostęp: 29.08.2018 r.]; Pontificium Consilium Instrumentis Communicationis Socialis, Instructio pastoralis „Communio et progressio", AAS 63(1971) 615-617.

16 Zob. J. Sobczak, Radiofonia i telewizja. Komentarz do ustawy, Zakamycze 2001, s. 273; E. Czarny-Drożdżejko [w:] J. Barta, R. Markiewicz, A. Matlak (red.), Prawo mediów, Warszawa 2008, s. 510-525. 
wyłącznie w godzinach od 23 do $6^{17}$. Do przepisów mających chronić dobro dzieci przed szkodliwością reklamy $\mathrm{w}$ radiofonii i telewizji należy także art. 16a ust. 6 pkt 4 URT, zawierający zakaz przerywania reklamami audycji dla dzieci. Ponadto, art. 16b ust. 2 URT zawiera zakaz nadawania przekazów handlowych, które nawołują bezpośrednio małoletnich do nabywania produktów lub usług; zachęcają ich do wywierania presji na rodziców lub inne osoby w celu skłonienia do zakupu reklamowanych produktów lub usług; wykorzystują zaufanie małoletnich, jakie pokładają oni w rodzicach, nauczycielach i innych osobach; w nieuzasadniony sposób ukazują małoletnich w niebezpiecznych sytuacjach. Zakazane są przekazy handlowe zawierające treści dyskryminujące ze względu na wiek (art. 16b ust. 3 pkt 3 URT). Zabronione są także przekazy handlowe zagrażające fizycznemu, psychicznemu lub moralnemu rozwojowi małoletnich. Warto podkreślić, że ten ostatni zakaz dotyczy wszystkich przekazów handlowych, stosownie do zamieszczonej wyżej uwagi w sprawie tzw. pory chronionej $\mathrm{w}$ dobowym czasie nadawania programu. Stanowisko takie wzmacnia ponadto fakt, że norma, ustanawiająca ten zakaz, jest przepisem szczególnym w relacji do ogólnych przepisów reglamentujących przekaz handlowy. Stosunkowo nowym jest aktualny przepis art. 16b ust. 3a URT, zgodnie z którym „,audycjom dla dzieci nie powinny towarzyszyć przekazy handlowe dotyczące artykułów spożywczych lub napojów zawierających składniki, których obecność w nadmiernych ilościach w codziennej diecie jest niewskazana”. Kwestia "papieskiej” reklamy adresowanej do dzieci, pozostaje zasadniczo poza zainteresowaniem polskiego prawodawcy, jeśli chodzi o reglamentację działalności prasowej w postaci prasy drukowanej oraz tych mediów internetowych, które nie podlegają reżimowi URT. Mają tu zastosowanie ogólne zasady powszechnie obowiązującego prawa. Brak ten wydaje się być szczególnie dotkliwy w sytuacji tego drugiego obszaru działalności medialnej. W konkluzji można stwierdzić, że w tych obszarach, które są objęte reglamentacją

17 Krajowa Rada Radiofonii i Telewizji wydała rozporządzenia szczegółowo reglamentujące kwestię ochrony małoletnich: z dnia 23 czerwca 2005 r. w sprawie kwalifikowania audycji lub innych przekazów mogących mieć negatywny wpływ na prawidłowy fizyczny, psychiczny lub moralny rozwój małoletnich oraz audycji lub innych przekazów przeznaczonych dla danej kategorii wiekowej małoletnich, stosowania wzorów symboli graficznych i formuł zapowiedzi, Dz. U. z 2005 r. Nr 130, poz. 1089, Dz. U. z 2011 r. Nr 155, poz. 923; z dnia 5 lutego 2013 r. w sprawie szczegółowych zasad ochrony małoletnich w audiowizualnych usługach medialnych na żądanie, Dz. U. z 2013 r. poz. 209. Szczegółowe ich omówienie wykracza poza ramy niniejszego artykułu. 
prawną URT, problem nadużyć kosztem dobra małoletnich, wynika raczej z braku odpowiedniego ${ }^{18}$ stosowania prawa, a nie braków w zakresie litery tego prawa.

Trzecim zagadnieniem, które zostało wyeksponowane już na wstępie Etyki w reklamie, jest problem wpływu „reklamodawców” na niezależność mediów, pojmowaną zarówno w aspekcie podmiotowym, jak i w aspekcie swobody w kształtowaniu rozpowszechnianych treści. „Istnienie wielu publikacji i stacji radiowo-telewizyjnych jest uzależnione od dochodów z reklamy. Dotyczy to często w równej mierze środków przekazu wyznaniowych, jak i komercyjnych. [...] To uzależnienie ekonomiczne środków przekazu oraz władza, jaką daje ono reklamodawcom, nakłada poważną odpowiedzialność na obydwie strony”. Ponadto „może być zagrożona również funkcja informacyjna samych mediów, gdy reklamodawcy próbują wywierać nacisk na publikacje lub programy radiowo - telewizyjne, aby nie poruszały tematów, które mogłyby się okazać kłopotliwe lub niewygodne. [...] Na tym właśnie polu może dojść do szczególnych nadużyć" (pkt III, 10).

Problem niezależności redakcyjnej nadawców jest przedmiotem zainteresowania polskiego prawodawcy ${ }^{19}$, niestety $\mathrm{w}$ stopniu nie odpowiadającym randze zagadnienia, zwłaszcza po kolejnych nowelizacjach URT, co jest przedmiotem krytyki w doktrynie ${ }^{20}$. Ciężar przeciwdziałania negatywnym zjawiskom $\mathrm{w}$ tej mierze ${ }^{21}$ został przerzucony na Krajową Radę Radiofonii i Telewizji, retorycznym obowiązkiem „stania na straży samodzielności dostawców usług medialnych" (art. 6 ust. 1 URT), za którym nie wydaje się iść odpowiednie instrumentarium. A przecież mamy $\mathrm{w}$ tym wypadku do czynienia $\mathrm{z}$ zagadnieniem rangi ustrojowej, czemu dał wyraz prawodawca $\mathrm{w}$ konstytucyjnej zasadzie wolności mediów zamieszczonej w art. 14 Konstytucji, zgodnie z którym „Rzeczpospolita

${ }^{18}$ W tym ze strony właściwych organów państwa, z Krajową Radą Radiofonii i Telewizji na czele. Celem zachowania obiektywizmu w powyższym zarzucie, należy zauważyć niedostatek w wyposażeniu Krajowej Rady Radiofonii i Telewizji w odpowiednie instrumentarium prawne w skorelowaniu z ogólnymi mankamentami wymiaru sprawiedliwości, o charakterze systemowym. Rozważając problem należy też mieć na uwadze skalę merkantylnych interesów potężnych grup medialnych i faktyczną (realną) pozycję tych ostatnich w przypadku ewentualnego zagrożenia tych interesów.

${ }_{19}$ Oraz europejskiego, zob. C. Banasiński, R. Rittler, M. Kolasiński, Prawo radiofonii i telewizji w Polsce w świetle standardów europejskich, Warszawa 2001, s. 57-99, 104-109.

20 Zob. M. Grabowski, Sponsoring telewizyjny, s. 150-157.

${ }^{21} \mathrm{~W}$ odniesieniu do radiofonii i telewizji. 
Polska zapewnia wolność prasy i innych środków społecznego przekazu”. Za słuszne należy uznać wypowiedzi, zgodnie z którymi cytowany przepis Konstytucji nakłada na państwo obowiązek zapewnienia wolności mediów za pomocą odpowiedniej działalności legislacyjnej, właściwej struktury i funkcjonowania organów państwa oraz bieżącej polityki państwa $^{22}$. Art. 13 ust. 1 URT stanowi, że „nadawca kształtuje program samodzielnie”, jednakże jedynym praktycznym walorem tego przepisu wydaje się być wskazanie podmiotu redakcyjnej odpowiedzialności, którym jest nadawca. Zgodnie z art. 14 ust. 1 URT, nałożenie na nadawcę obowiązku lub zakazu w zakresie rozpowszechniania programów, może nastąpić wyłącznie w drodze ustawowej. Od strony praktycznej, przepis ten jest wyrazem konstytucyjnych zasad, w tym wynikających $\mathrm{z}$ art. 31 ust. 3 Konstytucji. Więcej uwagi prawodawca polski poświęca niezależności nadawców w aspekcie sponsoringu i lokowania produktu. Art. 17 ust. 3 oraz art. 17a ust. 4 URT, zawierają bezwzględny zakaz wpływu sponsora lub lokującego na "samodzielność i niezależność redakcyjną nadawcy”. Zakaz ten dotyczy sytuacji takiego wpływu sponsora (lokującego), który narusza wolność mediów ${ }^{23}$. W odniesieniu do prasy drukowanej, powyższa problematyka nie jest przedmiotem zainteresowania polskiego prawodawcy, jeśli chodzi o szczególną reglamentację dotyczącą prasy. Tak samo jest w odniesieniu do tego obszaru działalności w Internecie, który nie podlega reżimowi URT. Mają tu zastosowanie ogólne zasady obowiązującego prawa.

\section{Pozytywne aspekty "reklamy”}

Wartym zaznaczenia, jest fakt, że w dokumencie Etyka $w$ reklamie została wyodrębniona część II Pozytywne aspekty reklamy, w całości poświęcona jej tytułowemu zagadnieniu. Jest to zabieg cenny, gdyż to właśnie aspekt dobra winien być od samego początku punktem odniesienia tak dla doktryny, jak i dla prawodawcy. Zachowany jest dzięki temu właściwy horyzont oraz proporcjonalność rozważanej reglamentacji prawnej.

\footnotetext{
${ }^{22}$ Zob. M. Sarnecki [w:] Prawo mediów, s. 17-22.

${ }^{23}$ Zob. M. Grabowski, Sponsoring telewizyjny, s. 152.
} 
Przywołana część II zawiera katalog pozytywnych ${ }^{24}$ aspektów promocji w zakresie:

1) wpływu na gospodarkę - „reklama” przyczynia się do rozwoju gospodarczego oraz do zaspokajania potrzeb społeczno-ekonomicznych. Jak zauważa Jan Paweł II, uczciwa "reklama”, wraz z cała, opartą na godziwych zasadach, nowoczesną ekonomią rynkową której jest fragmentem, może stanowić „najbardziej skuteczne narzędzie wykorzystania zasobów i zaspokajania potrzeb” społeczno-ekonomicznych ${ }^{25}$. Ponadto „reklama” jest pożytecznym narzędziem umożliwiającym zachowanie mechanizmów konkurencji w gospodarce, co przekłada się na spadek cen, wzrost dochodów, rozwój gospodarczy, tworzenie nowych miejsc pracy itd. ${ }^{26}$ Spełnia funkcję informacyjna, co przyczynia się do przemyślanych decyzji konsumenckich ${ }^{27}$. „Reklama” ułatwia także finansowanie środków społecznego przekazu, w tym katolickich;

2) wpływu na politykę - informacyjna funkcja „reklamy” ma szczególne znaczenie w systemie demokratycznym, gdyż ułatwia realizację tej jego cechy, którą ma być - jak zauważa Jan Paweł II - „udział obywateli w decyzjach politycznych [...] możliwość wyboru oraz kontrolowania własnych rządów" ${ }^{28}$. Ponadto, „reklama” polityczna daje szansę na kontakt z elektoratem wszystkim zainteresowanym, a nie tylko oligarchiom politycznym;

3) wpływu na kulturę - „reklamodawcy” mogą finansować produkcję programów wysokiej jakości ${ }^{29}$;

4) wpływu na życie moralne i religijne - np. poprzez rozpowszechnianie treści religijnych, patriotycznych, dobroczynnych ${ }^{30}$ itd. Dodat-

${ }^{24}$ Przy zastrzeżeniu uczciwości promocji, czyli poszanowania dobra człowieka i dobra wspólnego.

25 Jan Paweł II, Centesimus annus, 34, AAS 83(1991) 835-836.

${ }^{26}$ Sa to powszechnie podzielane w doktrynie prawnej i ekonomicznej pozytywne funkcje zjawiska konkurencji.

${ }^{27} \mathrm{~W}$ tym miejscu cytowany dokument stwierdza: „Pomaga konsumentom podejmować decyzje w sposób poinformowany i przemyślany”. Do modelu dobrze poinformowanego i rozważnego konsumenta odwołuje się ustawa z dnia 23 sierpnia 2007 r. o przeciwdziałaniu nieuczciwym praktykom rynkowym, Dz. U. 2017 r. poz. 2070, tekst jednolity. Zgodne z art. 2 pkt 8, tej ustawy, za przeciętnego konsumenta uważa się takiego, „który jest dostatecznie dobrze poinformowany, uważny i ostrożny".

${ }^{28}$ Jan Paweł II, Centessimus annus, 46, AAS 83(1991) 850.

${ }^{29}$ Co jest typową rolą właściwą dla sponsoringu w mediach. Bez finansowego wsparcia sponsorów wiele przedsięwzięć kulturalnych czy sportowych nie doszłoby do skutku.

${ }^{30}$ Taką będzie np. promocja celów realizowanych przez organizacje pożytku publicznego. 
kowo zaś, „obecność w sferze środków przekazu, w tym także w „reklamie", jest dla Kościoła dziś niezbędnym elementem ogólnej strategii duszpasterskiej"31.

\section{Pojęcie uczciwej „reklamy” w mediach}

Pojęcie uczciwej „reklamy” w mediach definiowane jest w papieskim nauczaniu nie tylko w aspekcie wskazanych wyżej pozytywnych aspektów promocji. Przede wszystkim precyzowane jest - a contrario - w odniesieniu do przesłanek nieuczciwej „reklamy”. Taka konstrukcja myślowa jest charakterystyczna dla polskiego prawodawstwa i doktryny, w których pojęcie uczciwej promocji budowane jest głównie w opozycji do negatywnych przesłanek. Ma to miejsce zwłaszcza w procesie stosowania prawa, gdy badane są konkretne stany faktyczne.

Rozdział III dokumentu Etyka w reklamie poświęcony jest nieuczciwej (szkodliwej) „reklamie”. Zawiera on przykładowy katalog czynów będących taką "reklamą". Wyliczenie to odpowiada metodologicznie powyższemu, które dotyczy pozytywnych aspektów reklamy. W rezultacie takiego zabiegu mamy do czynienia ze stosunkiem krzyżowania się przykładów lub ich powielania. Ze względu, na to, że obydwa podziały są ze sobą kontekstowo skorelowane, warto je zachować.

Do wymienionych w dokumencie ${ }^{32}$ czynów szkodliwej (nieuczciwej) „reklamy” należą w aspekcie:

${ }^{31}$ Zob. Papieska Rada ds. Środków Społecznego Przekazu, Instrukcja duszpasterska "Aetatis novae", Watykan 1992, s. 20-21.

${ }^{32}$ Egzemplifikacja czynów szkodliwej „reklamy” poprzedzona jest cytatem z Communio et progressio: „Reklamodawcy, którzy reklamują wyroby szkodliwe lub całkowicie bezużyteczne, którzy zachwalają nieistniejące zalety sprzedawanych towarów, którzy wyzyskują najniższe skłonności człowieka, szkodzą społeczeństwu, a ostatecznie sami tracą wiarygodność i dobrą reputację. Ale przynoszą szkodę osobom i rodzinom także ci reklamodawcy, którzy tworzą fikcyjne potrzeby i natarczywie zachęcają do nabywania towarów zbędnych, odbierając w ten sposób nabywcom środki na zaspokojenie podstawowych potrzeb. Powinni też unikać bezwstydnego wykorzystywania w reklamach treści erotycznych i seksualnych w celach komercyjnych oraz technik odwołujących się do podświadomości, które są zamachem na wolność nabywców" Pontificium Consilium Instrumentis Communicationis Socialis, Instructio pastoralis "Communio et progressio", 60, AAS 63(1971) 616. 
1) wpływu na gospodarkę: „,reklama”, która pomija lub ukrywa istotne fakty; tzw. „reklama” nierzeczowa ${ }^{33}$; „reklama” szerząca mentalność konsumpcyjną ${ }^{34}$; odwołująca się do instynktów, co narusza ludzką godność i dobro wspólne ${ }^{35}$; „reklama” uwłaczająca ludzkiej godności i dobru wspólnemu, poprzez ich „urynkowienie” (uprzedmiotowienie) ${ }^{36}$. Dokument powołuje się na słowa Jana Pawła: „Trzeba zawsze zachowywać świadomość, że «istnieją dobra, których ze względu na ich naturę nie można i nie należy sprzedawać i kupować», oraz unikać «bałwochwalczej» postawy wobec rynku, który przy współudziale reklamy lekceważy ten fakt o kluczowym znaczeniu" ${ }^{\prime 37}$;

2) wpływu na politykę: fałszywa „reklama” dyskredytująca konkurencję polityczną oraz inne programy polityczne; „reklama” nierzeczowa, tzn. odwołująca się do niskich uczuć, instynktów, przesądów rasowych oraz bazująca na uczuciach nieufności czy wrogości. Warto przywołać zawarte $\mathrm{w}$ tym punkcie dokumentu stwierdzenie, istotne dla życia politycznego i społecznego, zaczerpnięte z nauczania Jana Pawła II: „reklama” polityczna może blokować wolność polityczną. Tak jest wtedy, gdy „wysokie koszty reklamy ograniczają współzawodnictwo polityczne do kandydatów lub ugrupowań zamożnych albo zmuszają ubiegających się o stanowiska publiczne do rezygnacji ze swoich zasad i autonomii przez uzależnianie się od finansowego wsparcia grup interesów". Powyższe niech będzie postulatem (wprawdzie negatywnie sformułowanym) pod adresem polskiego prawodawcy. Postulat ten dotyczy mechanizmów i za-

${ }^{33}$ Określenie moje za terminologią polskiej doktryny, w szczególności dotyczącej nieuczciwej konkurencji. W powołanym dokumencie „reklama” ta jest opisana: „Często między podobnymi wyrobami różnej marki istnieją tylko bardzo nieznaczne różnice i wówczas reklama może nakłaniać odbiorców do podjęcia decyzji na podstawie motywów irracjonalnych (wierność określonej marce, prestiż, moda, sex appeal itp.), zamiast wskazywać na różnice jakości i cen wyrobów jako na kryterium rozumnego wyboru".

${ }^{34}$ Tzn. wzbudzająca pragnienie „posiadania dla samego posiadania”. Dokument powołuje się w tym miejscu na słowa Jana Pawła II: „Pragnienie, by żyć lepiej, nie jest niczym złym, ale błędem jest styl życia, który wyżej stawia dążenie do tego, by mieć, aniżeli być, i chce więcej mieć nie po to, aby bardziej być, lecz by doznać w życiu jak najwięcej przyjemności", Jan Paweł II, Centessimus annus, 36, AAS 83(1991) 839.

35 "Odwoływanie się bezpośrednio do instynktów [człowieka] i ignorowanie na różne sposoby jego wolnej i świadomej natury osobowej może prowadzić do wytworzenia nawyków konsumpcyjnych i stylów życia obiektywnie niegodziwych lub szkodliwych dla fizycznego lub duchowego zdrowia", Jan Paweł II, Centessimus annus, AAS 83(1991) 838-839.

${ }^{36}$ Kwalifikowaną postacią jest tu "reklama” naruszająca "godność i dobrobyt najuboższych i najsłabszych członków społeczeństwa, co zdarza się często".

37 Jan Paweł II, Centessimus annus, AAS 83(1991) 843. 
sad wyborczych w państwie, toteż rozważania w tej mierze wykraczają poza ramy niniejszej wypowiedzi. Nie można jednak nie zauważyć, przy tej okazji, realności groźby wykluczenia obywateli z życia społeczno-politycznego, które byłoby zaprzeczeniem istoty państwa i samej demokracji;

3) wpływu na kulturę: „reklama” narzucająca obce kulturowo wzor$\mathrm{ce}^{38}$; "reklama” "powierzchowna, wulgarna i niegodziwa”; "reklama” awychowawcza (np. skierowana do dzieci); „reklama” aspołeczna ${ }^{39}$; „reklama" poniżająca, w szczególności przez uwłaczające porównania dotyczące grup społecznych, zwłaszcza kobiet. Dokument egzemplifikuje „reklamę” poniżającą kobiety, poprzez ich uprzedmiotowienie, co niestety wymaga podkreślenia, $\mathrm{z}$ racji na negatywną - $\mathrm{w}$ tej mierze - praktykę prowadzenia promocji w Polsce. Na ten szkodliwy rodzaj „reklamy” zwraca szczególną uwagę Jan Paweł II, w swym nauczaniu kierowanym pod adresem mediów ${ }^{40}$;

4) wpływu na życie moralne i religijne: „reklama” naruszająca zasady moralne; "reklama” wulgarna; "reklama” demoralizująca; „reklama” odwołująca się do niskich uczućtil, "reklama” bezzasadnie szokująca; "reklama" podniecająca, tzn. erotyczna w swej treści lub kontekście - kwalifikowaną jej formą jest „reklama” perwersyjna czy pornograficzna" ; ,re-

38 „Należy pamiętać też o szkodach kulturowych wyrządzonych tym krajom i ich mieszkańcom przez reklamę, której treść i metody odzwierciedlają wartości dominujące $\mathrm{w}$ społeczeństwach rozwiniętych, a pozostają w konflikcie ze zdrowymi, tradycyjnymi wartościami kultur lokalnych. Dzisiaj ten typ dominacji i manipulacji, dokonywanej poprzez środki przekazu, budzi w krajach rozwijających się uzasadnioną obawę przed krajami rozwiniętymi, a także niepokój « ‘mniejszości w niektórych krajach»”, Papieska Rada ds. Środków Społecznego Przekazu, Instrukcja duszpasterska "Aetatis novae", Watykan 1992, s. 16.

${ }^{39}$ Tzn. nie odpowiadająca innym kryteriom demograficznym jej adresatów, takich jak np. wykształcenie, dochód itd.

40 "Ileż razy kobiety są traktowane nie jako osoby o niezbywalnej godności, ale jako przedmioty, które mają zaspokajać cudzą żądzę przyjemności lub władzy? Ileż razy lekceważy się czy wręcz ośmiesza rolę kobiety jako żony i matki? Ileż razy rolę kobiety w miejscu pracy i w życiu zawodowym ukazuje się tak, jakby była ona karykaturą mężczyzny, pomijając specyficzne cechy kobiecej intuicji, jej zdolność współczucia i zrozumienia, jakże istotną dla «cywilizacji miłości»", Jan Paweł II, Orędzie na XXX Światowy Dzień Środków Społecznego Przekazu. 24.01.1996, „L'Osservatore Romano” 17(1996), nr 6, https:// opoka.org.pl/biblioteka/W/WP/jan_pawel_ii/przemowienia/sdssp_24011996.html [dostęp: 29.08.2018 r.].

${ }^{41}$ Jak np. zawiść, dorobkiewiczostwo, chciwość.

42 „Upodobanie do przemocy i do pornografii to postawy bardzo pierwotne w doświadczeniu ludzkości, wyrażające najmroczniejsze wymiary ludzkiej natury [...] środki przekazu udostępniają pornografię i obrazy przemocy szerokiej publiczności, w tym także 
klama” odwołująca się do przemocy; „reklama” wykorzystująca w celach komercyjnych treści religijne (np. motywy, symbole, postacie, obrazy) oraz moralne; "reklama” produktów lub usług oraz postaw i wzorców sprzecznych z zasadami moralnymi ${ }^{43}$;

5) inne postacie nieuczciwej (szkodliwej) reklamy, wymienione w pkt IV: „reklama” nawołująca do niegodziwych (szkodliwych) zachowań; „reklama” nakłaniająca w sposób niemoralny i demoralizujący; „reklama" manipulująca za pomocą nowoczesnych środków technicznych; „reklama” ukryta ${ }^{44}$, w tym „reklama” oddziałująca na podświadomość, czyli podprogowa (subliminalna); "reklama” przesadnie zachwalają$\mathrm{ca}^{45}$; "reklama” kłamliwa, polegająca na fałszu ${ }^{46}$, pozorowaniu prawdy lub przemilczeniu istotnych faktów; "reklama” wprowadzająca w błąd, w jakikolwiek sposób. Jak stwierdza Jan Paweł II: „Godziwe korzystanie z prawa do informowania wymaga, aby treść przekazywanej informacji była prawdziwa i - przy zachowaniu zasady sprawiedliwości i miłości kompletna. Wiąże się z tym nakaz unikania w każdym przypadku jakiejkolwiek manipulacji prawdą"47; "reklama” naruszająca godność człowieka w jakikolwiek sposób, w tym poprzez takie formy oddziaływania na odbiorcę, które negatywnie wpływają na wolność wyboru ${ }^{48}$; „reklama” bazująca na ludzkich słabościach ${ }^{49}$; "reklama” naruszająca godność oraz

młodzieży i dzieciom. Ta demoralizująca praktyka była kiedyś ograniczona do krajów bogatych, obecnie jednak za sprawą środków przekazu zaczyna podważać wartości moralne krajów rozwijających się", Papieska Rada ds. Środków Społecznego Przekazu, Pornografia i przemoc w środkach społecznego przekazu: odpowiedź duszpasterska, Watykan 1989, s. 6.

${ }^{43}$ Dokument podkreśla, że ten typ „reklamy” narusza dobro człowieka i dobro wspólne „Przytoczmy tu jako przykład reklamę środków antykoncepcyjnych i poronnych oraz produktów szkodzących zdrowiu, wspomagane przez rządy kampanie reklamowe na rzecz sztucznej kontroli urodzin, tak zwanego «bezpiecznego seksu» i tym podobnych praktyk", ( Pkt III, d. 13, akapit 6. Kodeksu Etyka w reklamie).

${ }_{44}$ Przed odbiorca, który nie ma świadomości faktu promocji.

${ }^{45}$ Tzn. w nadmiernym, co do atrakcyjności, kontekście. Taką jest np. budowanie skojarzeń z popularnymi postaciami.

${ }^{46}$ Niezgodność podawanych faktów z rzeczywistością.

47 Jan Paweł II, Przemówienie do specjalistów od środków przekazu, Los Angeles. 15.09.1987. http://mateusz.pl/dokumenty/ewr.htm [dostęp: 02.04.2018 r.].

48 „W reklamie winien absolutnie obowiązywać nakaz poszanowania ludzkiej osoby, jej prawa i obowiązku odpowiedzialnego wyboru, jej wewnętrznej wolności; wszystkie te wartości zostałyby podeptane, gdyby odwoływano się do najniższych skłonności człowieka lub gdyby została ograniczona jego zdolność do refleksji i do dokonywania wyboru", Paweł VI, Środki społecznego przekazu..., „L'Osservatore Romano” 13.05.1977, s. 1-2.

49 „Tego typu nadużycia [...] rzeczywiście występują dziś w wielu reklamach. Reklama może obrażać godność człowieka zarówno przez swoją treść - to, co jest reklamowane 
prawa dzieci i rodziców, w tym wykorzystująca łatwowierność dzieci lub nakłaniająca je do wywierania presji na rodziców; "reklama” odwołująca się do uczuć lęku ${ }^{50}$; reklama „,antyekologiczna”, tzn. taka, która propaguje styl życia niszczący środowisko naturalne ${ }^{51}$.

\section{Wnioski i postulaty wynikające z papieskiego nauczania dotyczącego "reklamy"}

Dokument Etyka w reklamie, wzywając do odpowiednich zmian prawnych, postuluje ich oparcie na trzech podstawowych zasadach wynikających z prawa naturalnego (pkt IV): prawdomówności "reklamy”, poszanowaniu w "reklamie” godności osoby oraz szeroko pojętej odpowiedzialności w działalności „reklamowej” za społeczne skutki „reklamy". Wypada zgodzić się z tymi postulatami. Dwa pierwsze - jako skorelowane ze sobą ${ }^{52}$ - mają nadrzędne znaczenie. Ich niezachowanie skutkuje nadużyciami $\mathrm{w}$ całym, poruszanym $\mathrm{w}$ niniejszej wypowiedzi, zakresie „reklamy”. W odniesieniu do prawa do prawdy i jego miejsca w mediach, Jan Paweł II zauważa nierozerwalny związek między prawdą i wolnością. Bez prawdy nie ma wolności. Jednocześnie zaś, każda przekazywana informacja, w tym „reklama”, winna mieć „godziwą i odpowiednią” formę, sposób i treść przekazu. Jak stwierdza cytowany papież, w „reklamie” winno być bezwzględnie zachowane prawo do prawdy oraz szacunek dla godności ludzkiej. „Reklama” nie powinna więc nigdy wprowadzać w błąd. "Godziwe korzystanie z prawa do informowania wymaga, aby treść przekazywanej informacji była prawdziwa i - przy zachowaniu zasady sprawiedliwości i miłości - kompletna. Wiąże się z tym nakaz unikania

i w jaki sposób jest reklamowane jak i przez swoje oddziaływanie na odbiorców. Mówiliśmy już o budzeniu uczuć chciwości, próżności, zazdrości i pożądliwości oraz o technikach, które manipulują ludzką słabością i ją wykorzystują. W takich przypadkach reklamy stają się nieuchronnie «przekaźnikami zniekształconej wizji życia, rodziny, wartości religijnych i moralnych, wizji nie respektującej prawdziwej godności i przeznaczenia człowieka»", Papieska Rada ds. Środków Społecznego Przekazu, Pornografia i przemoc, s. 7.

${ }^{50}$ Zwłaszcza, gdy adresowana jest do ludzi starszych lub „upośledzonych kulturowo”.

${ }^{51}$ Przykładowo przez marnotrawienie zasobów naturalnych lub ich rabunkową eksploatację.

${ }^{52}$ Prawo do prawny osadzone jest w godności osoby ludzkiej. 
w każdym przypadku jakiejkolwiek manipulacji prawdą"53. Jeśli chodzi, o trzeci, powyższy postulat, w nauczaniu Jana Pawła II podkreślane są m.in.: niezbędność realizacji tego postulatu dla umożliwienia rozwoju człowieka $\mathrm{w}$ aspekcie życia indywidualnego i społecznego (rodzina, naród itd.) ${ }^{54}$ oraz wskazana już wyżej kwestia „ekologiczności” reklamy ${ }^{55}$.

Za konkluzję powyższych postulatów może służyć wypowiedź polskiego papieża: „Podstawowym obowiązkiem twórców reklam, podobnie jak wszystkich innych zawodowo pracujących w innych środkach społecznego przekazu, jest być rzecznikami i promotorami autentycznej wizji ludzkiego rozwoju w jego wymiarach materialnych, kulturowych i duchowych" 56 .

Adresatami postulatów i stanowisk zawartych w powyższym nauczaniu dotyczącym „reklamy”, są uczestniczący w działalności „reklamowej” oraz prawodawcy.

Jeśli chodzi o tych pierwszych, punktem wyjścia jest konstatacja, że nic nie zastąpi właściwych postaw ludzi zaangażowanych $\mathrm{w}$ działalność „reklamową”. W myśl maksymy, że prawo bez obyczajów jest martwe. Do zaangażowanych w "reklamę" sformułowany jest postulat wprowadzenia właściwych rozwiązań w kodeksach etyki zawodowej. „Zadaniem agencji reklamowych, pracowników sektora reklam, a także kierujących środkami przekazu, które stają się nośnikami reklam, jest upowszechnianie i stosowanie opracowanych już kodeksów deontologii, tak aby można było przy pomocy opinii publicznej doskonalić je i sprawić, że będą przestrzegane w praktyce" (pkt IV. 19 Kodeksu Etyka w reklamie).

Prawodawcy winni stanowić prawa realizujące zawarte $\mathrm{w}$ powyższym nauczaniu postulaty. W szczególności, skonkretyzowany jest postulat w zakresie reklamy kierowanej do dzieci. „Także reklama polityczna mogłaby stać się terenem podatnym na regulację prawną, określająca, jakie sumy wolno na nią przeznaczyć, kto i w jaki sposób może zbierać pieniądze potrzebne na reklamę itp." (pkt IV. 20 Kodeksu Etyka w reklamie).

Wydaje się, że reklamowe postulaty, wskazane w nauczaniu Stolicy Apostolskiej, znalazły zasadniczo swój wyraz w polskiej reglamentacji prawnej dotyczącej radiofonii i telewizji. Można jednak wskazać, że

${ }^{53}$ Jan Paweł II, Przemówienie do specjalistów od środków przekazu, Los Angeles. 15.09.1987, http://mateusz.pl/dokumenty/ewr.htm [dostęp: 02.04.2018 r.].

${ }^{54}$ Jan Paweł II, Solicitudo rei socialis, 33, AAS 80(1988) 557.

55 Jan Paweł II, Centesimus annus, 37, AAS 83(1991) 840.

56 Jan Paweł II, Solicitudo rei socialis, 27-34, AAS 80(1988) 547-560. 
w odniesieniu do wszystkich mediów pożyteczne byłyby zmiany legislacyjne, o czym poniżej.

Rozpatrzenie w tym miejscu całej przedmiotowej reglamentacji prawnej wykracza poza ramy artykułu, wymagałoby to kilku wypowiedzi o charakterze monograficznym. Toteż ograniczam się do aktów prawnych, których naczelnym ${ }^{57}$ celem jest reglamentacja działalności medialnej. Należy do nich ustawa z dnia 26 stycznia 1984 r. prawo prasowe ${ }^{58}$, zwana dalej „UPR” oraz cytowana już URT.

Ustawa prawo prasowe wprawdzie dotyczy wszystkich rodzajów mediów, jednakże - ze względu na szczególne w stosunku do niej przepisy URT - praktycznie ma znaczenie w odniesieniu do prasy drukowanej. Przepisy UPR zawierają zakaz promocji sprzecznej z prawem lub zasadami współżycia społecznego oraz nakaz takiego oznaczenia faktu promocji, aby był on czytelny dla adresata (art. 36 ust. 2 i 3 UPR). Natomiast warto podkreślić zawarty w tej ustawie obowiązek, dotyczący wszystkich mediów, w tym także elektronicznych "prawdziwego przedstawiania omawianych zjawisk" (art. 6 ust. 1 UPR).

Przepisy URT zawierają szereg postanowień odpowiadających tytułowemu nauczaniu, do których należą, oprócz powołanych wyżej, przy zagadnieniu dziecięcej oraz politycznej „reklamy”:

${ }^{57}$ Pomijam, więc inne akty prawne. Promocja w mediach może być, przykładowo, czynem nieuczciwej konkurencji, w szczególności takim czynem w zakresie reklamy, o którym mówi art. 16 ustawy z dnia 16 kwietnia 1993 r. o zwalczaniu nieuczciwej konkurencji, Dz. U. z 2003 r. Nr 153, poz. 1503; z 2004 r. Nr 96, poz. 959; Nr 162, poz. 1693; Nr 172, poz. 1804; z 2005 r. Nr 10, poz. 68; z 2007 r. Nr 171, poz. 1206; z 2009 r. Nr 201, poz. 1540; z 2017 r. poz. 933, 1132). Może być także nieuczciwą praktyką rynkową w rozumieniu przepisów, w szczególności art. 4 i 5, ustawy z dnia 23 sierpnia 2007 r. o przeciwdziałaniu nieuczciwym praktykom rynkowym, Dz. U. z 2017 r. poz. 2070, tekst jednolity. Czy też, praktyką naruszającą zbiorowe interesy konsumentów, np. zgodnie z art. 24 ust. 2 pkt 3, ustawy z dnia 16 lutego 2007 r. o ochronie konkurencji i konsumentów, Dz. U. z 2017 r. poz. 229, 1089, 1132. Ponadto, ma tu zastosowanie szereg ustaw reglamentujących różne dziedziny, a zwierających także normy zakazujące lub ograniczające promocję w mediach.

${ }^{58}$ Dz. U. z 1984 r. Nr 5, poz. 24; Dz. U. z 1988 r. Nr 41, poz. 324; Dz. U. z 1989 r. Nr 34, poz. 187; Dz. U. z 1990 r. Nr 29, poz.173; Dz. U. z 1991 r. Nr 100, poz. 442; Dz. U. z 1996 r. Nr 114, poz. 542; Dz. U. z 1997 r. Nr 121, poz. 770; Dz. U. z 1997 r. Nr 88, poz. 554; Dz. U. z 1999 r. Nr 90, poz.999; Dz. U. z 2001 r. Nr 112, poz. 1198; Dz. U. z 2002 r. Nr 153, poz. 1271; Dz. U. z 2004 r. Nr 111, poz. 1181; Dz. U. z 2005 r. Nr 39, poz. 377; Dz. U. z 2007 r. Nr 89, poz. 590; Dz. U. z 2010 r. Nr 182, poz. 1228; Dz. U. z 2011 r. Nr 85, poz. 459; Dz. U. z 2011 r. Nr 156, poz. 934; Dz. U. z 2011 r. Nr 205, poz. 1204; Dz. U. z 2011 r. Nr 282, poz. 1660; Dz. U. z 2010 r. Nr 235, poz. 1551; Dz. U. z 2012 r. poz. 1136; Dz. U. z 2013 r. poz. 771 . 
1) nakaz takiego oznaczania faktu promocji, aby odbiorca o nim wiedział. Ma to przeciwdziałać wprowadzającej w błąd, ukrytej promocji (art. 16 ust. 1, 2, 6; art. 17 ust. 1, art. 17a ust. 2 i 3);

2) ograniczenia czasu reklam oraz możliwości przerywania audycji reklamami. Przeciwdziała to m.in. negatywnej komercjalizacji, o której mowa w nauczaniu (art. 16 ust. 3, 5, 6; art. 16a ust. 1-7). W tym też zakaz przerywania reklamami audycji o treści religijnej (art. 16a ust. 6 pkt 2), co odzwierciedla, $\mathrm{w}$ pewnym zakresie, zawarty w nauczaniu papieskim postulat niewykorzystywania $\mathrm{w}$ celach komercyjnych treści religijnych. A także przywołany wyżej zakaz przerywania reklamami audycji dla dzieci;

3) zakazy w zakresie promocji określonych produktów lub usług, dotyczące tytoniu, alkoholu ${ }^{59}$, określonych świadczeń zdrowotnych i produktów leczniczych, hazardu, środków psychotropowych (odurzających), solarium ${ }^{60}$ (art. 16b ust. 1). Zakazy te mają również charakter podmiotowy, $\mathrm{w}$ odniesieniu do związanych $\mathrm{z}$ wymienionymi produktami (usługami) sponsorów audycji oraz lokujących produkty (usługi), tak aby przeciwdziałać ukrytej promocji tych produktów (usług) - odpowiednio art. 17 ust. 2 , ust. 5 pkt 4 , ust. 6 -6a oraz art. 17a ust. 6 URT. Niewątpliwym ratio legis tych zakazów jest ochrona zdrowia odbiorców promocji, czyli poszanowanie, w tym zakresie, ich godności;

4) będące wprost realizacją odpowiednich postulatów z papieskiego nauczania: zakazy przekazów handlowych oddziałujących w sposób ukryty na podświadomość, naruszających godność ludzka; zawierających treści dyskryminujące ze względu na rasę, płeć, narodowość, pochodzenie etniczne, wyznanie lub światopogląd, niepełnosprawność, wiek (postulat „reklamy” uspołecznionej); raniących przekonania religijne lub polityczne; sprzyjających zachowaniom zagrażającym zdrowiu, bezpieczeństwu lub ochronie środowiska (postulat „reklamy” ekologicznej); zakaz ukrytych przekazów handlowych, lokowania tematów ${ }^{61}$; zakaz promocji zawierającej treści propagujące działania sprzeczne $\mathrm{z}$ prawem oraz postawy i poglądy sprzeczne z moralnością i dobrem społecznym, w szczególności nawołujące do nienawiści lub dyskryminujące ze względu na

59 Niestety, spod zakazu „wyjęte” jest piwo, co jest negatywnym rozwiązaniem legislacyjnym, zob. M. Grabowski, Sponsoring telewizyjny..., s. 195 i nast.

${ }^{60}$ Od dnia 16.02.2018 r.

${ }^{61}$ Zakaz z art. 16c pkt 2 URT, dotyczący lokowania produktów jest praktycznie obezwładniony szerokimi wyjątkami. 
rasę, niepełnosprawność, płeć, wyznanie lub narodowość; zakaz promocji nie szanującej przekonań religijnych odbiorców, a zwłaszcza chrześcijańskiego systemu wartości; zakaz promocji sprzyjającej zachowaniom zagrażającym zdrowiu lub bezpieczeństwu oraz zachowaniom zagrażającym środowisku naturalnemu; ponadto - w odniesieniu do nadawców publicznych - ustawa uwydatnia nakazy ${ }^{62}$ respektowania, przez promocję chrześcijańskiego systemu wartości, dobra rodziny, właściwych postaw prozdrowotnych oraz zwalczaniu patologii społecznych (art. 16b ust. 2 i 3; 16c, 18 ust. 1-3; 21 ust. 2 URT) $)^{63}$.

W konkluzji zawartych wyżej uwag, można stwierdzić, że obowiązująca w Polsce reglamentacja dotycząca promocji w radiofonii i telewizji zasadniczo odpowiada postulatom papieskiego nauczania w sprawie uczciwości „reklamy”. Przynajmniej, jeśli chodzi o porównanie zakresów tego nauczania i medialnej reglamentacji. Niestety, niektóre z ustawowych nakazów, dotyczących dopuszczalnej treści „reklamy”, mają retoryczny wydźwięk w praktyce działalności medialnej. Wydaje się, że główna odpowiedzialność za to spoczywa raczej na praktyce stosowania prawa, niż na samej jego literze. Wskazane byłyby jednak, de lege ferenda, zmiany. Niektóre, nie tyle $\mathrm{z}$ racji na braki legislacyjne, lecz $\mathrm{z}$ uwagi na powyższą praktykę. Inne, ze względu na potrzebę zmian ustawodawczych celem ochrony istotnych dóbr.

Do tych pierwszych należy, wskazana wyżej kwestia poszanowania godności kobiet, która należy do wymienionych expressis verbis $\mathrm{w}$ URT: ludzkiej godności i zakazu dyskryminacji ze względu na płeć. Wskazane byłoby wpisanie w treść art. $16 \mathrm{~b}$ ust. 3 i art. 18 ust. 1 URT, nakazu poszanowania godności kobiet. Korzystne mogłoby być także wyeksponowanie obowiązku poszanowania praw rodziców w wymienionych przepisach URT oraz w cytowanej reglamentacji dotyczącej ochrony małoletnich.

Do drugiego rodzaju zmian, winny należeć co najmniej dwie kwestie. Po pierwsze, jest to problem niezależności redakcyjnej mediów. Jeśli chodzi o prasę drukowana, ustawodawca podchodzi do zagadnienia raczej

${ }^{62}$ Te i tak można wyprowadzić z wyliczonych wyżej zakazów promocji.

${ }^{63}$ Szczegółowe zasady dotyczące reklamy, sponsoringu i lokowania, określają rozporządzenia Krajowej Rady Radiofonii i Telewizji: z dnia 30 czerwca 2011 r. w sprawie sposobu prowadzenia w programach radiowych i telewizyjnych działalności reklamowej i telesprzedaży, Dz. U. z 2014 r. poz. 204, tekst jednolity; z dnia 6 lipca 2000 r. w sprawie sposobu sponsorowania audycji lub innych przekazów, Dz. U. z 2014 r. poz. 203, tekst jednolity; z dnia 30 czerwca 2011 r. w sprawie szczegółowych warunków lokowania produktów, Dz. U. z 2011 r. poz. 977. 
symbolicznie. W przypadku nadawców elektronicznych wskazany byłby powrót do zniesionych w URT ograniczeń procentowego udziału podmiotu stosującego promocję, w budżecie jednego nadawcy. Podobne rozwiązanie powinno być przyjęte $\mathrm{w}$ odniesieniu do prasy drukowanej. Zmiany te są potrzebne zwłaszcza w odniesieniu do sponsoringu. Po drugie, istnieje problem „reklamy” politycznej. Brakuje tu adekwatnych ograniczeń dopuszczalnych wydatków na "reklamę” polityczna, w tym wyborczą. Podzielając papieski postulat w tej kwestii, oraz jego uzasadnienie, należy proponować wprowadzenie, w polskim prawie, radykalnych ograniczeń dotyczących wydatków finansowych. Zmiany winny dotknąć promocję „polityczną”, zwłaszcza zaś wyborcza, na wszystkich polach wypowiedzi, tzn. we wszelkiego rodzaju mediach (drukowanych, elektronicznych) oraz w obszarze poza medialnym, np. „reklama” uliczna.

Oprócz odpowiednich zmian legislacyjnych, wskazane jest upowszechnianie przytoczonego nauczania w zakresie "reklamy”, wśród uczestników rynku promocji, wraz z postulatem odpowiedniej implementacji tego nauczania w branżowych (zawodowych) kodeksach dobrych obyczajów zwłaszcza, że zawarta w tym nauczaniu argumentacja, nie sprowadza się do stanowisk o charakterze wyznaniowym, lecz odwołuje się do prawno-naturalnych pojęć dobra człowieka i dobra wspólnego. Stąd jej uniwersalność także w odniesieniu do wszystkich adresatów na rynku promocji. W prawdziwej perspektywie dobra papieskie postulaty przyczyniają się do poszanowania dóbr wszystkich stron rynku promocji ${ }^{64}$ : zaangażowanych w działalność „reklamową” oraz odbiorców „reklamy”.

Słowa kluczowe: promocja, reklama, sponsoring, lokowanie produktu, media

\section{Bibliografia}

Banasiński C., R. Rittler, M. Kolasiński, Prawo radiofonii i telewizji w Polsce w świetle standardów europejskich, Warszawa 2001.

Barta J., R. Markiewicz, A. Matlak (red.), Prawo mediów, Warszawa 2008. dla nich.

${ }^{64}$ Nawet, gdyby w krótkowzrocznej perspektywie, miałyby uchodzić za niekorzystne 
Barta J., M. Kępiński, R. Markiewicz, M. Poźniak-Niedzielska, T. Skoczny, R. Skubisz, S. Sołtysiński, J. Szwaja, I. Wiszniewska, Ustawa o zwalczaniu nieuczciwej konkurencji. Komentarz, J. Szwaja (red.), Warszawa 1994.

Gajlewicz M., Reklama i jej uwarunkowania, „Przegląd Ustawodawstwa Gospodarczego" 1993, nr 10, s. 2-6.

Gajlewicz M., Reklama i pojęcia pokrewne, „Przegląd Ustawodawstwa Gospodarczego" 1993, nr 10, s. 6-9.

Garbarski L., I. Rutkowski, W. Wrzosek, Marketing. Punkt zwrotny nowoczesnej firmy, Warszawa 2001.

Grabowski M., Sponsoring telewizyjny. Aspekty prawne i praktyczne, Kraków 2015.

Grabowski M., Sponsoring. Kwalifikacja prawna, Lublin 2013.

Jan Paweł II, Centesimus annus, Watykan 1991.

Jan Paweł II, Orędzie na XXX Światowy Dzień Środków Społecznego Przekazu. 24.01.1996, „L'Osservatore Romano" [wyd. pol.]17(1996), nr 6, https://opoka.org.pl/biblioteka/W/WP/jan_pawel_ii/przemowienia/sdssp_24011996. html [dostęp: 29.08.2018 r.].

Jan Paweł II, Przemówienie do specjalistów od środków przekazu, Los Angeles. 15.09.1987. http://mateusz.pl/dokumenty/ewr.htm [dostęp: 29.08.2018 r.].

Jan Paweł II, Solicitudo rei socialis, Watykan 1988.

Jaworska-Dębska B., Wokót pojęcia reklamy, „Przegląd Ustawodawstwa Gospodarczego" 1993, nr 12, s. 20-24.

Kall J., Reklama, Warszawa 1998.

Łodzianowska-Grabowska J., Efektywność reklamy, Warszawa 1996.

Nowińska E., Zwalczanie nieuczciwej reklamy. Zagadnienia cywilno-prawne, Kraków 2002.

Papieska Rada ds. Środków Społecznego Przekazu, Etyka w reklamie, „L' Osservatore Romano" [wyd. pol.] 18(1997), nr 11, s. 40-46.

Papieska Rada ds. Środków Społecznego Przekazu, Instrukcja duszpasterska "Aetatis novae", Watykan 1992.

Papieska Rada ds. Środków Społecznego Przekazu, Pornografia i przemoc w środkach społecznego przekazu: odpowiedź duszpasterska, Watykan 1989.

Paweł VI, Środki społecznego przekazu: korzyści - niebezpieczeństwa - odpowiedzialność. Orędzie na XI Światowy Dzień Środków Społecznego Przekazu 1977, „L'Osservatore Romano" 13.05.1977, nr 1/2, https://www.paulus.org. pl/256,11-sdssp-pawel-vi-1977 [dostęp: 29.08.2018 r.].

Pontificium Consilium Instrumentis Communicationis Socialis, Instructio pastoralis "Communio et progressio", AAS 63(1971) 593-656.

Preussner-Zamorska J., Aksjologiczne uwarunkowania reklamy, „Zeszyty Naukowe Uniwersytetu Jagiellońskiego. Prace z Wynalazczości i Ochrony Własności Intelektualnej" 1993, nr 62, s. 55-68.

Preussner-Zamorska J., Uwagi na temat zakazu reklamowania wolnych zawodów, „Rejent” 1994, nr 3, s. 14-32.

Skubisz R., Zakaz reklamy napojów alkoholowych, „Rejent” 1995, nr 10, s. 9-23. 
Sobczak J., Radiofonia i telewizja. Komentarz do ustawy, Zakamycze 2001.

Sztucki T., Promocja. Sztuka pozyskiwania nabywców, Warszawa 1995.

Szwaja J. (red.), Ustawa o zwalczaniu nieuczciwej konkurencji. Komentarz, Warszawa 2006.

Szwaja J. (red.), Ustawa o zwalczaniu nieuczciwej konkurencji. Komentarz, Warszawa 2013.

Traple E., J. Adamczyk, P. Barta, X. Konarski, W. Kulis, P. Litwiński, Z. Okoń, M. Ożóg, P. Podrecki, G. Sibiga, M. Świerczyński, T. Targosz, Prawo reklamy i promocji, Warszawa 2007.

Wiszniewska I., R. Skubisz, Środki zapobiegania nieuczciwej reklamie w projekcie ustawy o zwalczaniu nieuczciwej konkurencji, „Państwo i Prawo” 1995, nr 4, s. $49-56$.

\section{REGARDING THE CONCEPT OF HONEST ADVERTISING IN THE MEDIA, PROPOSED IN THE TEACHING OF JOHN PAUL II}

\section{S u m m a r y}

In the teaching of John Paul II there are suggested solutions relating to advertising in the media. Some are suitable to be directly included into Polish law, while others require "only" be translated to the correct Polish legal system legislative language. Certainly, we have to deal with ready-made solutions that should be placed in codes of ethic.

The arguments contained in the teaching of John Paul II refers to the natural concepts of human good and the common good. Therefore the recommendations for advertising have a universal character.

In Poland, the legal regulation concerning the promotion in broadcasting essentially corresponds to the demands of the Papal teaching on the honesty of advertising. It seems that the deficiencies in terms of the honesty of advertising rather apply to practice the application of the law.

Visible is the lack of proper regulation in relation to promotion in printed press and electronic media, which are not subject to the regime of the law on broadcasting.

There should be changes to regulation of the promotion in all media. This applies to the above lack of in this regulation. In addition, there is a need for changes leading to the adequate protection of the dignity of women, the rights of parents, independence of the media and political promotion, including electoral advertising.

Key words: promotion, advertising, sponsoring, product placement, broadcasting 


\section{В ДЕДЕ ПОНЯТИЯ ПРАВДИВОСТИ РЕКЯАМЫ В СМИ, КОТОРЫЙ СОДЕРЖИТСЯ В УЧЕНИЯХ ИОАННА ПАВЛА І I}

$$
\text { Р е } 3 \text { ю м е }
$$

В учении Иоанна Павла II содержатся предложения по решений относитедьно рекламы в СМИ. Одни предоставляются открыто к внедрению в польском праве, а другие требуют „только” перевода на законодательный язык в соответствующей польской правовой системе. Безусловно, мы имеем дело с готовыми решениями, которые должны содержаться в так называемых кодексах добрых обычаев.

Аргументация, которая содержится в учении Иоанна Павла II, касается юридическо-натуральных понятий блага человека и общего блага. Поэтому постулаты рекламы имеют универсальный характер.

Обязательная в Польше юридическая регламентация, касающаяся акции в радио и телевидении принципиально соответствует постулатам папского учения в деле правдивости рекламы. Кажется, что отсутствия в сфере правдивости рекламиы относятся скорее практики применения права.

Видимое отсутствие соответствующей регламентации относительно акции в печатной прессе, а также электронных СМИ, которые не подлежат режиму закона о радиовещании и телевидении.

Следует постулировать, de lege ferenda, изменения, касающиеся регламентации акции во всех СМИ. Это касается вышеупомянутого дотсутствия в данной регламентации. Кроме того, происходит потребность изменений, которые ведут к соответствующей охране достоинства женщин, правам родителей, независимости СМИ и политической акции, в том избирательной рекламы.

Кдючевые слова: акция, реклама, спонсорство, размещение продукта, СМИ 